Interdisciplinary Contexts of Special Pedagogy
NUMBER 29/2020

\title{
Students with special educational needs in distance learning during the COVID-19 pandemic - parents' opinions
}

\begin{abstract}
Maria Trzcińska-Król, Students with special educational needs in distance learning during the COVID-19 pandemic - parents' opinions. Interdisciplinary Contexts of Special Pedagogy, no. 29, Poznań 2020. Pp. 173-191. Adam Mickiewicz University Press. ISSN 2300-391X. e-ISSN 2658-283X. DOI: https://doi.org/10.14746/ikps.
\end{abstract} 2020.29.08

This article focuses on how children with special educational needs, psychological and pedagogical opinions and advice and guidance on how to work with them, and their parents are coping in a distance learning situation. Four research problems have been formulated, i.e., What changes do parents notice in the child's motivation to learn during distance learning education? What limitations and difficulties arise with distance learning education? What are the attitudes of children during distance learning in the opinions of their parents? Do parents notice any progress in their children's learning during distance learning education? For research on the key methods used and interview technique. The research was conducted on the basis of the opinions of parents, who during distance learning education were strongly involved in the educational processes of their children, and often took on the role of a teacher. Self-study for children is limited by the challenge, cannot be met, and remote learning evokes great emotions in them. In the opinion of parents, distance learning education tools are not conducive to the focus of attention on the part of their children.

KEY WORDS: parents, opinions, children with special educational needs, distance learning 
The presence of modern technologies in the lives of children and youth is a fact. A computer with access to the Internet, a phone, a tablet have been and still are tools used at various levels, e.g. as a form of "spending free time, a desired element of lifestyle, an instrument for communicating, teaching or finally as a source of danger" $^{\prime 1}$ The manner in which we use these tools can bring positive results, enrich us and our actions, be constructive or on the contrary, contribute to destruction, disintegration, destruction of personality, psyche, behaviour. In the school environment, when children and young people attended regular school classes, many parents tried to limit their children's access to new technologies, especially in the case of younger students, often treating access to ICT (Information and Communication Technology) tools as a reward, or as a form of entertainment after school duties have been fulfilled. In the current epidemiological situation, due to the closure of schools and forced isolation, ICT tools have become the only channel of communication between teachers and children and the tools that allow for the realization of educational processes. All participants in these processes had to switch from the option of using ICT tools in education, to the necessity of using them, regardless of their competences, skills, technological capabilities. Teachers had to change the forms and methods of work and transfer the methods of activating the learner, which have a huge impact on the effectiveness of learning, into virtual reality, regardless of their digital competences. And as research shows, these are varied. Both the digital competences of parents, teachers and students themselves. ${ }^{2}$ The schools were closed and distance learning was introduced.

Among the solutions used in remote education one can indicate: e-mails, electronic school registers, conference tools, communicators,

${ }^{1}$ P. Plichta, J. Pyżalski, Wstęp, [in:] Wychowanie i ksztatcenie w erze cyfrowej, ed. P. Plichta, J. Pyżalski, Regional Centre of Social Policy in Łódź, Łódź 2013, p. 7.

2 J. Pyżalski, A Zdrodowska, Ł. Tomczyk, K. Abramczuk, Polskie badanie EU Kids Online 2018. Najważniejsze wyniki i wnioski, Scientific Publishing House of Adam Mickiewicz University in Poznań, Poznań 2019. 
tools enabling group work. The solutions, methods and techniques of remote education adopted by the school depended, among others, on the capabilities of the school, teachers and students. Regardless of the adopted form of teaching, parents were strongly involved in their children's remote education.

Such a drastic change made the author focus on the situation of children with special educational needs ${ }^{3}$ and how they and their parents cope with remote education? The focus of both classical and remote education is determined by different types of special educational needs. The identification of special educational needs through the prism of learning difficulties has allowed the identification of a group of parents whose children have a decision or opinion from

${ }^{3}$ Until recently, special educational needs were related to children and adolescents with disabilities, social maladjustment and behavioural disorders. They now apply to all children who "have clearly greater learning difficulties than most of their peers, regardless of whether the source of these problems is organic damage or not" (Olechowska, 2016, p. 27). Thus, they refer to all students who may have learning difficulties regardless of their cause. "Four main areas of special educational needs are recognized: 1) communication and interpersonal contacts, 2) thought processes and information acquisition, 3) behaviour, emotions and social development, 4) sensory and/or physical development" (Noworyta, 2013, p. 433). Special educational needs also apply to gifted students. The Ordinance of the Minister of National Education of 9 August 2017 on the principles of organizing and providing psychological and pedagogical assistance in public kindergartens, schools and institutions includes students with special abilities among those in need of psychological and pedagogical assistance. For decades, a gifted child has been considered an exceptional, above-average, a prodigy child who did not require support from educational institutions. However, as the study by Dyrda (2000) shows, a gifted child is very often a pupil with underachievement syndrome. Łukasiewicz-Wieleba (2018), on the other hand, mentions low motivation, lack of perseverance and social difficulties (ibid., p. 352) among the elements having negative impact on the development of a gifted person. Friedman-Nimz and Skyba (Friedman-Nimz, Skyba, 2009, pp. 421-436) point out that outstanding abilities are not without influence on self-esteem and functioning in society. Other researchers emphasize the rather negative impact of the possessed abilities on the self-esteem of such a person and his or her needs for achievement (Silverman 1991, Jackson et al. 2009, after: Knopik, 2018, p. 16). 
a psychological-educational counselling centre regarding recommendations and guidelines for working with the student in the classroom.

Learning is closely linked to the attention mechanism, which consists of three interrelated processes: attention orientation (receptors), attention selectivity and the ability to organize information. ${ }^{4}$ Control over all three mechanisms is essential for effective learning. Very often in the case of students with special educational needs, we encounter a dysfunction of one of these mechanisms and the students have recommendations and guidelines for work. Attention is directed, among others, by motivational processes ${ }^{5}$ that stimulate action, challenges and exploration. They direct our actions leading to a specific result. The basic way of motivating students to learn is external motivation, expressed by school grades. ${ }^{6}$ Internal motivation, defined as an innate propensity to develop one's own abilities, to challenge and seek novelty, to explore and learn, is the most desirable and sufficient stimulator in itself. Motivation can result from the desire to succeed or avoid failure. It is influenced not only by environmental stimuli (e.g. the environment in which the child is raised) but also by physical and mental predispositions. The development of children's motivation is greatly influenced by parents' involvement in educational processes, which manifests itself e.g. through taking care of intellectual development, arousing interests, discovering the world.7 Excessive requirements have a demotivating effect, so it is important to adapt the requirements to the abilities of the students, especially those with special educational needs. For reasons beyond their control, they are not able to achieve the same results as their peers, therefore they should be supported.

${ }^{4}$ R.E. Franke, Psychologia motywacji, GWP, Gdańsk 2006, p. 57.

${ }^{5}$ Ibid., p. 60.

${ }^{6}$ M. Głoskowska-Sołdatow, Wybrane aspekty motywowania uczniów do nauki, [in:] Edukacja dziecka - mity i fakty, ed. E. Jaszczyszyn, J. Szada-Borzyszkowska, Trans Humana Wydawnictwo Uniwersyteckie, Białystok 2010, p. 422.

7 J. Niepokólczycka-Gac, Skuteczne budowanie motywacji do nauki, Portaloswiatowy.pl, 2011. https://www.portaloswiatowy.pl/organizacja-zajec-szkolnych/skutecz ne-budowanie-motywacji-do-nauki-9584.html [1.08.2020]. 


\section{Research methodology}

The aim of the research was to learn about the situation of a child with special educational needs, the limitations and problems faced by children and their parents during the period of distance learning and progress in learning.

The subject of research included the parents' statements targeted with questions concerning the situation and learning of a child during the period of distance learning.

Four research problems were formulated:

1) Do parents see any changes in their child's motivation to learn during remote education and what kind of changes?

2) What limitations and difficulties have emerged as a result of remote learning?

a. What actions have the parents taken to support their child in the educational process?

3) According to the parents what kind of behaviour does the child present during remote learning?

4) What progress has been made in their child's learning during remote learning, if any?

The paper uses the key case method, which is a "heuristic strategy of cognitive behaviour, characterized by the fact that it is a kind of research reconnaissance, intended to provide approximate answers to questions about the existence, characteristics, genesis, structure, functions, etc. of a certain object or phenomenon...". ${ }^{8}$ It is applicable when other methods fail, when it is difficult to find a pattern of conduct, when there is no theory related to the explored area that could be an inspiration or there is a lack of practical experience in the explored topic. Finding key cases, i.e. people important for the research, allows to get to know the issue, obtain answers to research questions. ${ }^{9}$ The difficulty of this method is to generalize

8 A. Góralski, Metoda Przypadków kluczowych, [in:] Metody badań pedagogicznych w zarysie, ed. A. Góralski, Wyższa Szkoła Pedagogiki Specjalnej im. Marii Grzegorzewskiej, Warszawa 1989, p. 118.

${ }^{9}$ Ibid., p. 118. 
the results. Generalization based on the study of small groups may not be reflected in the regularities of other communities or populations. The most reasonable technique in the case of this method is the interview, which is an appropriately targeted process of interaction between the interlocutors, i.e., the researcher and the surveyed person, requiring the ability to listen carefully and not to impose own opinions and views. ${ }^{10}$ Kvale $^{11}$ writes that an interview is "a specific form of conversation in which knowledge is created in the course of interaction", but unlike it, it is targeted and subordinated to a set goal. ${ }^{12}$

The research uses the technique of free, partially categorized interview, which leaves a large scope of freedom to ask questions to the surveyed person, and at the same time does not exclude the possibility of asking previously prepared questions, but requires us to ask them in a different way and in a different order from the one previously established. It allows to ask both open and closed questions, as well as those not included in the interview questionnaire. ${ }^{13}$ The interview was open and individual in nature. In order to carry out the research, an interview questionnaire was prepared. In the situation of limited contacts, the interview was conducted with the use of ICT tools after prior appointment of an interview date convenient for the parents.

The selection of the sample was purposeful and was carried out among the parents of students from four different elementary school, i.e. three public elementary schools: in Skierniewice, Piastów, Warsaw and one social elementary school in Warsaw. Parents of school-age children attending 3rd, 4th, 5th, and 6th grade ele-

${ }^{10}$ M. Łobocki, Wprowadzenie do metodologii badań pedagogicznych, Oficyna Wydawnicza „Impuls”, Kraków 1999, p. 245.

11 S. Kvale, Prowadzenie wywiadów, Wydawnictwo Naukowe PWN, Warszawa 2010, pp. 19-20.

12 S. Gudkova, Wywiad w badaniach jakościowych, [in:] Badania jakościowe. Metody $i$ narzędzia, ed. D. Jemielniak, Vol. 2, Wydawnictwo Naukowe PWN, Warszawa 2012, p. 112.

${ }_{13}$ M. Łobocki, Metody i techniki badań pedagogicznych, Oficyna Wydawnicza „Impuls”, Kraków 2011, p. 269. 
mentary school were interviewed, including three mothers and one father of students with special educational needs.

The research was conducted between May 11th and 13th, 2020 among the parents of students who have a decision or opinion of a psychological-educational counselling centre concerning the methods of working with the child, adjusting the requirements, forms and methods of work to the child's perception capabilities. The information obtained has been organized and developed in terms of the research problems posed.

\section{Characteristics of the boys}

The first boy described by a mother (M1) is 11 years old and attends the 5th grade of elementary school. He belongs to the group of children who began compulsory schooling at the age of 6 . The boy was diagnosed with Asperger's syndrome in the first grade of elementary school and has difficulties in focusing attention and recommendations concerning, among other things, longer working time. Currently, at school the boy is under the care of a supporting teacher, a psychologist and a school pedagogue.

The second boy, also described by a mother (M2), is 9 years old and attends the third grade of elementary school. He was diagnosed with Asperger's syndrome in 2016. The boy has difficulty in focusing attention, sound hypersensitivity. At school he has a supporting teacher and a psychologist.

Information about the third boy was also provided by the mother (M3). He is a pupil from the group of children who began compulsory schooling at the age of 6 , but his parents took steps to postpone his compulsory education for one year and as a result he went to school a year later than his peers and is now in the fourth grade of elementary school. The diagnosis at the counselling centre was carried out in the first grade of elementary school due to reported problems with concentration and auditory memory. He attends corrective and compensatory classes at school, has recommenda- 
tions, including: longer working time, making eye contact with the child when saying the instructions, directing the child's activity during lessons.

Information about the fourth child was provided by the father (T1). The boy is 13 years old and attends the sixth grade of elementary school, has directional and analytical skills and attends additional classes. He was referred to the counselling centre because of social problems (e.g. he did not remember the names of the children from his class) and long working time reported by the teachers.

The following part of the article will present the results of the research according to the order of the research questions posed.

\section{The child's motivation to learn during remote education}

With regard to three boys, the parents stated that they did not observe increased motivation to study, but rather expressed their opinion that it simply did not exist.

[...] Generally, his motivation for school is poor. It was poor, so to speak, before and is bad now [...]. And it is hard, it is very hard. To motivate him to study at all, especially since there is a problem with certain kids, well... there is no supporting teacher at the moment. And we just have to do it, everything is on our shoulders. (M1)

He has never had an inner motivation to learn, he has always been externally motivated and it's the same now. He certainly has no motivation to learn. (M3)

[...] I ask him, I explain and so on, but ... he has no motivation. (M2)

The situation was completely different in the case of the fourth boy, whose parents observed a great deal of self-motivation to perform English exercises in the first week of isolation. This was motivated by the fact that he did not have to perform these tasks for the next two weeks. In the following weeks, the father no longer observed increased motivation in his son. 
One of the topics addressed in the interviews was the children learning on their own. The information obtained shows that all the boys must be supported and controlled by their parents. In relation to three boys, the mothers said they had to do the homework with the child and help him learn the new material provided by the teachers.

Leaving him unattended is... difficult, because he wouldn't learn by himself [...]. And he didn't do the work in class... (M1)

When I stand over him and tell him to read the task, he will do it in 10 minutes. So I tell him: look, you've done it in 10 minutes and it wasn't difficult at all. (M2)

Of course, you have to sit down with him [...] and do the homework together with him. (M3)

In the case of the fourth boy, after the introduction of a system for recording homework in a special notebook designed for this purpose, he was able to take greater control and became more independent in learning.

\section{The limitations and difficulties that emerged with remote education}

In relation to individual children, parents talked about huge problems resulting from, among other things, a disturbance of the existing rhythm and work system, which gave the children a sense of security and harmonized their actions.

Lessons at school were always lessons [...]. He did something there. It was a completely different situation [...]. Now, unfortunately, everything has changed. For the worse, I think. It will be difficult to return to this rhythm. (M1)

They signalled that the beginnings of remote learning were very difficult for both children and parents. They pointed out the follow- 
ing problems: new tools, new forms of work, their inadequacy to the methods and possibilities of children's work. Parents were concerned about the way of preparing materials for pupils to learn, the incompatibility of attachment names in the text materials and the attached files. The father of one of the boys mentioned too many platforms and tools that emerged with remote learning. Lack of information about the topics or homework in one place forced the child to constantly search the platforms used by the teachers for particular lesson topics, which was very time-consuming.

At the beginning it was a nightmare [...]. The teachers wrote something. Partly they wrote to the parents for the child to do something, partly to the child. [...] the following week the Microsoft cloud was introduced, and then there was the Outlook, the chat room, the Teams, the tasks on the Teams. Some of the teachers used the register, some of them worked differently. So the whole system of assignments has changed a lot. [...] although there are also wallets and tablets and what not... and you have to check all that, which is difficult. The mish-mash, generally speaking. (T1)

The boy needed about 45 minutes a day to find all the information about what to do and what homework to prepare for the next lessons.

In the case of two pupils, the mothers stated that the school did not conduct online classes with the children and the teachers only sent information about what the students were supposed to do for a given lesson. In their opinion there was no explanation, no discussion of a given part of material on the part of the teachers, which forced them to enter into the role of a teacher and to explain the discussed lessons to their child.

This is what the classes look like: we get [...] a list of tasks that the child should do on a given day, i.e. read the text, answer the questions, do the tasks in the exercise book, analyse them, i.e. to work independently, and the teacher doesn't really help with anything. (M2) 
$[\ldots]$ the teacher sends the material [...] to be read and exercises to be done. There are teachers who are available in a classroom chat during these classes. (M3)

The three mothers talked about the problems their children faced during their education not only in distance learning, but also in the classroom. These included problems with concentration. In their opinion, remote education does not help with concentration, and the materials prepared by the teachers do not take into account the needs of children with special educational needs.

[...] He has a problem with imagining some things, but he has a big problem with ... writing questions to a text. He does not understand, he writes the answers (M2)

[...] the way the maths teacher conducted lessons on Messenger... It is often the case that he does not keep up. [...] What is the main problem? It is the problem with concentration, so if there is too much material, or the number of students who answer the same question and suddenly there are 10 answers, it is chaos for him ... and he is not able to keep up. (M3)

The biggest challenge for parents in remote education was to reconcile their own work with the fact that at the same time they had to become teachers for their children. This was an overwhelming and burdensome situation for them. The opinion I often heard in the interviews was: "It's hard, it's just hard". Leaving children alone with this form of learning, in the opinion of mothers, would result in educational failure. They quoted attempts by their children to work on their own, which ended in failure.

It is worth noting that all parents developed their own solutions to the emerging difficulties. One of the mothers who had problems with reconciling her own work with her son's education asked the assistant teacher to support the child in learning new material and doing homework during online meetings. In his case, the teachers did not provide on-line lessons, but sent the materials for independent study. 
So finally I decided that somebody should help me and I think that is the role of the supporting teacher [...] to help my child. (M2)

Other parents took on the role of the teacher, trying to explain a given part of the material discussed by the teacher, so that the child could understand and perform the tasks themselves.

[...] it must be clearly said that it [learning - author's note] does not take more time... but this is because the parents are involved and perform the role of the teacher. (M3)

Or, as in the case of the gifted boy, it was enough for the teachers to put all the information in one place, so as not to look for it in different places, platforms, registers, emails used by the teachers.

$[\ldots]$ now we simply write it all down in the notebook. [...] he saves it to check Outlook or somewhere else. And somehow he manages. (T1)

In the parents' opinion, time spent by the students at the computer is a big problem now. Previously, all the surveyed guardians said that children could use the tool at a certain time. In the given educational situation it would not be possible to realize the teaching processes - learning without modifying the rules, which has an impact on the children and their behaviour, therefore parents tried to find a solution and e.g. set time for work at the computer, but also breaks to rest without ICT tools.

\section{The students' behaviour in remote learning situations}

A big problem for children was not only the form of teaching itself, but also the verification of knowledge. Online tests evoked a lot of emotions, were a source of additional stress and frustration. For one boy, for example, the pressure of time, as well as the novelty of the tool with which the test was performed, evoked such strong emotions that the boy had big problems writing it. 
There was a situation when the teacher prepared a test [...]. And of course we had a terrible brawl. [...] Perhaps he got upset that he was under time pressure, that he had to do it. [...] he started to get aroused and [...] he didn't write anything. [...]. I know that he had the knowledge. But once he go into this spiral... (M1)

Parents also noticed the silencing of certain emotions connected with the child's functioning in school, in a peer group. They said that children have become calmer, less nervous. They feel more at ease. The guardians of all the children noted that they were happy with the solution that allowed them to study at home without having to go to school. Two students treated this situation as a holiday and were quite reluctant to study.

The fact that the students had to explore the material that was previously explained by the teacher and that it took much more time and effort on their part was a source of some rebellion and aversion to learning.

The difficult part is that now he has to read everything. This is what he said to me: "At school, I only read two lines and you make me read the whole page." [...] he doesn't understand why he has to do so much. Because he has noticed [...] that now he must do everything [...] by himself. (M2)

Of course, there were also students who tried to cope with boredom during remote lessons and performed additional activities.

He invents some kind of machines in class, he programs in Scratch instead of learning biology, for example. He has two monitors, on his laptop and this one... So on one of them he has the biology teacher and on the other, let's say Scratch, so... it was Python before, wasn't it? This is how he tried to deal with boredom in class. He is bored, for example, in mathematics [...], but he tries to do something during the maths exercises [...]. He plays with the computer, for example, he creates thousands of catalogues, or writes something in Scratch, or... or tries to do something in Python. (T1) 


\section{Learning progress}

The new situation has forced new solutions. All participants of the educational processes had to start using remote education tools, computers with Internet access, phones, tablets. As the research shows, everyday use of these tools contributed to the development of students' computer skills. With regard to all children, parents talk about the development of digital competences.

[...] Because... this is really computer- and internet-based learning, there is certainly some progress in this area. (M3)

The rest of the parents spoke in a similar tone. However, the guardians also noticed that the computer was not only an attractive tool for children, but also slowed down their work.

The learning itself, without the computer, ... would have been more effective, to sum up. (T1)

The assessment of progress in home schooling is completely different. Despite systematic lessons and verification of the level of mastery of the material through tests, some parents have doubts about the quality of learning and what their children are getting out of it.

But now he knows... I mean, he knows these are lessons, but he doesn't take them too seriously. He knows he has to do them and that's it. (M1)

One of the guardians also observed that in the current situation, all additional subject activities have been suspended, which was at a loss to his son, as he did not develop mathematically. During the learning process carried out in the school environment such classes not only gave him pleasure, but also provided additional knowledge about the subject which is his passion.

[...] the does not develop mathematically, and that is a problem, he does not develop in physics [...] in school during the half hour he had fun [...] the problem is with mathematical and physics development. (T1) 


\section{Conclusion}

Never before have schools been closed on such a scale. Teachers, parents and pupils alike have found themselves in an uncomfortable situation, which has created many challenges for all participants in the educational process. For teachers, it meant an accelerated course in using the tools enabling to them carry out lessons, changing the way, forms and methods of teaching, verifying the pupils' knowledge. For parents, greater support of children in learning, helping the children use the tools, controlling their children's learning process. Finally, for the children themselves, greater independence in exploring the content of the lesson, participation in activities often carried out with the use of Internet platforms. What had previously been used as an additional option, a possibility, became a compulsion. At first the rapid shift from one way to the other (a remote education system unverified on such a scale) caused great chaos. Each teacher carried out his or her lessons in a way that was beneficial to them, preferring their own tools, sometimes without taking the children's abilities into account. They often prepared materials that did not take into account individual preferences, the needs of children, especially children with special educational needs. In the presented research it seems that teachers did not take into account the cognitive and emotional-social capabilities of their pupils, especially those with special educational needs. Sending lessons and homework materials on different platforms, the incompatibility of file names in the materials with the names of the attachment created unnecessary confusion. Teachers seemed to forget that every "content appearing on the platform should be selected according to the specific participants, their abilities, interests and needs". ${ }^{14}$ The disruption of the existing rhythm of work, changes in the way of learning, the emergence of new tools, new ways of

${ }_{14}$ N. Walter, Mamy (za) duży wybór - jak nie zgubić się wśród narzędzi cyfrowych?, [in:] Edukacja w czasach pandemii wirusa COVID-19, ed. J. Pyżalski, EduAkcja, Warszawa 2020, p. 52. 
communication with teachers is a big problem for students. Parents, not only parents of children with Asperger's syndrome, pointed out that the disruption of the current order of the day caused frustration, nervousness, an inability to find themselves in the new situation. It took time to adapt to the changes.

The current form of education is not home schooling, but distance learning in a situation of crises ${ }^{15}$, requiring a great deal of students' independence, the will to learn, greater commitment and effort put into familiarizing themselves with the lessons, reading, understanding the material. As the presented research shows, independent learning is a big challenge for children, one they are not able to meet. However, it is worth emphasizing that all parents were strongly involved in their children's educational processes and have found solutions that helped to support their children, e.g. one of the mothers asked for support from the school, the supporting teacher. The mothers said they took on the role of the teacher and worked together with the child, explaining the material. The father, on the other hand, claimed that it was enough to change the way of sending the information by the teacher (listing all the tasks, instructions in one place) for the child to become more independent in the learning process. All parents talked about controlling their children's work, i.e., keeping an eye on: the learning, the homework or doing tests. In the case of three of the boys, attempts to learn independently in the remote education system failed.

New tools, new methods of teaching and learning, the verification of knowledge evoked a lot of emotions. Fear of the new, ignorance of the tools does not serve the purpose of assimilation of knowledge by pupils. It caused nervous situations, prevented normal functioning and learning. These situations were very stressful for children and were not conducive to learning. The high level of stress and its intensity is "a natural enemy of memorizing and, more

${ }^{15}$ A. Doucet, D. Netolicky, K. Timmers, J. Tuscano, Thinking about Pedagogy in an Unfolding Pandemic School Closures, Independent Report written to inform the work of Education International and UNESCO, 2020, p. 33. https://issuu.com/education ninternational/docs/2020_research_covid-19_eng [14.05.2020]. 
generally, learning" ${ }^{16}$ The computer with Internet access is a very attractive tool, used to a limited extent during regular education conducted at school, and parents noticed significant progress in their children's computer skills, however, it was also the cause of numerous problems for students in remote education. In the opinion of parents, this form of learning does not encourage concentration of attention, children have problems with reading and analysing the information that appears simultaneously.

In order to make education "effective", it is necessary to use methods that activate the student, i.e. those that engage his or her senses, imagination or emotions". ${ }^{17}$ It is not enough to tell them what to read, what tasks to do in the book or exercise book. We cannot transfer the methods used in a classroom environment to remote education because they will not work. In the learning process, a student needs a teacher who will support and mentor him/her, motivate and guide him/her. When it is not possible for a teacher to provide such support through synchronous communication channels, the role of the teacher is taken over by the parents. However, it is important to remember that parents will not be able to spend their entire days educating their children. ${ }^{18}$

The information obtained is burdened with the subjective assessment of the respondents and is not a source of factual information. However, from an exploratory point of view, it is an opportunity to learn the parent's point of view and assess the situation. ${ }^{19}$

${ }^{16}$ M. Kaczmarzyk, Neurobiologiczny kontekst edukacji zdalnej, [in:] Edukacja w czasach pandemii wirusa COVID-19, ed. J. Pyżalski, EduAkcja, Warszawa 2020, p. 24.

17 N. Walter, Mamy $(z a)$ duży wybór - jak nie zgubić się wśród narzędzi cyfrowych?, [in:] Edukacja w czasach pandemii wirusa COVID-19, ed. J. Pyżalski, EduAkcja, Warszawa 2020, p. 52.

18 A. Doucet, D. Netolicky, K. Timmers, J. Tuscano, Thinking about Pedagogy in an Unfolding Pandemic School Closures, Independent Report written to inform the work of Education International and UNESCO, 2020, p. 33. https://issuu.com/educationin ternational/docs/2020_research_covid-19_eng [14.05.2020].

19 S. Gudkova, Wywiad w badaniach jakościowych, [in:] Badania jakościowe. Metody i narzędzia, ed. D. Jemielniak, Vol. 2, Wydawnictwo Naukowe PWN, Warszawa 2012, p. 116. 


\section{References}

Doucet A., Netolicky D., Timmers K., Tuscano J., Thinking about Pedagogy in an Unfolding Pandemic School Closures, Independent Report written to inform the work of Education International and UNESCO, 2020. https://issuu.com/educationinter national/docs/2020_research_covid-19_eng [14.05.2020].

Franke R.E., Psychologia motywacji, GWP, Gdańsk 2006.

Friedman-Nimz R., Skyba O., Personality Qualities That Help or Hinder Gifted and Talented Individuals, [in:] International Handbook on Giftedness, ed. L. Shavinina, Springer Netherlands, 2009, pp. 421-436.

Głoskowska-Sołdatow M., Wybrane aspekty motywowania uczniów do nauki, [in:] Edukacja dziecka - mity i fakty, ed. E. Jaszczyszyn, J. Szada-Borzyszkowska, Trans Humana Wydawnictwo Uniwersyteckie, Białystok 2010, pp. 422-431.

Góralski A., Metoda Przypadków kluczowych, [in:] Metody badań pedagogicznych w zarysie, ed. A. Góralski, Wyższa Szkoła Pedagogiki Specjalnej im. Marii Grzegorzewskiej, Warszawa 1989, pp. 118-121.

Gudkova S., Wywiad w badaniach jakościowych, [in:] Badania jakościowe. Metody i narzędzia, ed. D. Jemielniak, Vol. 2, Wyd. Naukowe PWN, Warszawa 2012, pp. 111-130.

Kaczmarzyk M., Neurobiologiczny kontekst edukacji zdalnej, [in:] Edukacja w czasach pandemii wirusa COVID-19, ed. J. Pyżalski, EduAkcja, Warszawa 2020, pp. 20-24.

Knopik T., Uczeń zdolny jako uczeń ze specjalnymi potrzebami edukacyjnymi, [in:] Języki Obce w Szkole, No. 3/2018, pp. 13-18.

Kvale S., Prowadzenie wywiadów, Wyd. Naukowe PWN, Warszawa 2010.

Łobocki M., Wprowadzenie do metodologii badań pedagogicznych, Oficyna Wydawnicza „Impuls”, Kraków 1999.

Łobocki M., Metody i techniki badań pedagogicznych, Oficyna Wydawnicza „Impuls”, Kraków 2011.

Łukasiewicz-Wieleba J., Rozpoznawanie potencjatu oraz wzmocnienia $i$ ograniczenia rozwoju zdolności dzieci w narracjach rodziców, Wyd. APS, Warszawa 2018.

Niepokólczycka-Gac J., Skuteczne budowanie motywacji do nauki, Portaloswiatowy.pl, 2011. https://www.portaloswiatowy.pl/organizacja-zajec-szkolnych/skutecznebudowanie-motywacji-do-nauki-9584.html [1.08.2020].

Noworyta A., Podmiotowość ucznia zdolnego - ucznia ze specjalnymi potrzebami edukacyjnymi, [in:] Szkoła twórcza w odtwórczym świecie. Biblioteka Wspótczesnej Myśli Pedagogicznej, Vol. 2. ed. J. Krukowski, A. Wołoch, Wydział Pedagogiczny Uniwersytetu Pedagogicznego im. Komisji Edukacji Narodowej w Krakowie, Kraków 2013, pp. 431-444.

Olechowska A., Specjalne potrzeby edukacyjne, Wyd. Naukowe PWN S.A., Warszawa 2016.

Pilch T., Bauman T., Zasady badań pedagogicznych. Strategie ilościowe i jakościowe, Wyd. Akademickie „Żak”, Warszawa 2010. 
Plichta P., Pyżalski J., Wstęp, [in:] Wychowanie i ksztatcenie w erze cyfrowej, ed. P. Plichta, J. Pyżalski, Regional Centre of Social Policy in Łódź, Łódź 2013.

Pyżalski J., Zdrodowska A., Tomczyk Ł., Abramczuk K., Polskie badanie EU Kids Online 2018. Najważniejsze wyniki i wnioski, Scientific Publishing House of Adam Mickiewicz University in Poznań, Poznań 2019.

Walter N. Mamy (za) duży wybór - jak nie zgubić się wśród narzędzi cyfrowych?, [in:] Edukacja w czasach pandemii wirusa COVID-19, ed. J. Pyżalski, EduAkcja, Warszawa 2020, pp. 51-58. 